Canadian University Music Review

Canadian University Music Review

Revue de musique des universités canadiennes

\title{
The New Generation of Composers in Quebec
}

\section{Alan Belkin}

Volume 9, numéro 2, 1989

URI : https://id.erudit.org/iderudit/1014905ar

DOI : https://doi.org/10.7202/1014905ar

Aller au sommaire du numéro

Éditeur(s)

Canadian University Music Society / Société de musique des universités

canadiennes

ISSN

0710-0353 (imprimé)

2291-2436 (numérique)

Découvrir la revue

Citer cet article

Belkin, A. (1989). The New Generation of Composers in Quebec. Canadian University Music Review / Revue de musique des universités canadiennes, 9(2),

22-35. https://doi.org/10.7202/1014905ar

All Rights Reserved (C Canadian University Music Society / Société de musique des universités canadiennes, 1989
Ce document est protégé par la loi sur le droit d'auteur. L'utilisation des services d'Érudit (y compris la reproduction) est assujettie à sa politique d'utilisation que vous pouvez consulter en ligne.

https://apropos.erudit.org/fr/usagers/politique-dutilisation/ 


\title{
THE NEW GENERATION OF COMPOSERS IN QUEBEC
}

\author{
Alan Belkin
}

\section{INTRODUCTION}

Who are the new composers of serious musicl in Quebec today? What do they think about their art and their musical environment? Following an idea originally proposed by Carolyn Jones, Marie-Thérèse Lefebvre (professor of musicology at the Université de Montréal), Mireille Gagné (director of the Montreal branch of the Canadian Music Centre) and I attempted to answer these questions. With financial help from our respective institutions, we interviewed 25 of the younger composers in Quebec.

We originally hoped to publish the interviews together in a book. However, it became apparent that they could only be homogenized to a consistent format with great difficulty: there were too many important differences in style, tone, degree of detail, and quality of expression. Since this material is a treasure of first-hand documentation about the state of music in Quebec today, coming from the people at the centre of it, we hope that, in the future, someone will undertake a lengthier study of it. For the moment, this article summarizes the main findings so as to bring the material to the notice of the musical community. Some quotations will convey a little of the flavour of the interviews. ${ }^{2}$

1 By serious music I mean "art music" in which the composer's intent is not primarily commercial.

2 All quotations and their respective page citations are taken from the volume, Regards sur la musique actuelle au Québec, which is available through the Montreal branch of the Canadian Music Centre. Translations are by the author. As they appear in this volume, the interview transcripts have been considerably cut and reworked both by the researchers and the composers themselves. Cassettes of the original interviews as well as the first transcriptions, uncut and unedited, are also deposited at the Canadian Music Centre in Montréal. 
The interviews were conducted according to a questionnaire, a copy of which is appended to this article. We divided this questionnaire into five areas: musical background; the process of composition; aesthetic attitudes; "professional" matters, having to do with money; and finally, extra-musical, cultural issues. Each area was explored in a series of questions, and the interviewee was left free to expand as necessary within this framework. No interview lasted more than one hour, and all were taped. The language of the interview was chosen by the composer.

The following composers responded. ${ }^{3}$

Raynald Arsenault
Gilles Bellemare
Alan Belkin
Richard Boucher
Michelle Boudreau
Walter Boudreau
Michel-Georges Brégent
Brian Cherney
José Evangelista
Claude Frenette
Michel Gonneville
Denis Gougeon
Robert Jones

Andre Lamarche Alain Lalonde Anne Lauber Michel Longtin Robin Minard Antoine Padilla John Rea Donald Steven Keith Tedman Paul Théberge Pierre Trochu John Winiarz

Our first criterion for selection was simply age: no composer could be older than his/her forties at the time of the interviews in 1984 . We set this limit so as to exclude more established composers whose opinions were already well documented elsewhere. In the case of the younger composers, we excluded those still in school at any level lower than doctoral studies. Another criterion was residence: the composer had to have lived for a substantial time in Quebec and had to be currently making his/her career there.

\section{MUSICAL BACKGROUND}

3 Several composers who were away or otherwise unavailable during the period when we conducted the interviews had to be left out. These included Denis Lorrain, Denis Bouliane, and Jean Piché. A number of other composers refused an interview or withdrew the interview for personal reasons. These include Myke Roy, Yves Daoust, and Marcelle Deschênes 
The first part of the questionnaire addressed the composer's musical background. In trying to pinpoint their first musical interests, a few composers said they "just knew young" that they were going to compose. Some composers, like Michel Gonneville who came from a musical family, cited an older person who acted as a catalyst. Some, like Michel-Georges Brégent, began by playing classical repertoire on an instrument. Many composers mentioned the influence of the popular music they heard around them. Since this popular music came largely from records and the radio, and since the instrumental repertoire they came to know as children consisted largely of European classical music, it is perhaps not surprising that most of these composers have come to see themselves more as "world composers" than as "Quebec composers."

It is striking that only three of the 25 composers mentioned their school as being musically significant (and one of these, Robert Jones, was American-schooled). Unlike many places in the U.S., Quebec does not have an elaborate music program in its schools. Good school choirs and bands are relatively rare. One wonders what the effect on Quebec serious music would be if more intensive and serious musical education were available from primary school up.

We asked the composers about their musical education. No composer totally lacked performing background; not surprisingly, a majority considered it a very important element in their early musical training. In fact, a number of composers said that their first musical ambitions had been as performers. A composer like Walter Boudreau, who played professionally at a very young age, absorbed much of his musical knowledge in this way.

We also asked each composer whether she/he had been thoroughly trained in the conventional "writing skills" (harmony, counterpoint, etc.). Only four composers said they had not had rigorous training in this area. While no one disputed the importance of this kind of training, many expressed strong reservations about the way writing skills are often transmitted. In general, the main objections focussed around an overly academic approach, divorced from "real" music, and limited in style.

When we asked the composers to evaluate their training as a whole, most professed satisfaction with their own training. Many, however, had suggestions to improve what they saw as the inadequate current situation in music education. What they said is best expressed in their own words. 
For the part of a composer's education that takes place in an institution to be at least adequate, it should be open, vast, systematic, and intense; it should leave some time for contemplation; it should touch the issue of jobs; all in all, it should be connected to life.

[ Michel Gonneville, p. 62 ]

One of the things that has come about from my experience as a teacher of composition over the last ten years, and which I think is a telling point, is that 80 to 90 percent of composers don't think of themselves as working in a field which has anything to do with art. They think they are isolated in some way and that they have a very special private activity. I discovered that many people, although they don't realize this, go into composition as a form of therapy which has nothing to do with music. It's using music as a form of therapy - not doing music ... What gets taught in the academies, apparently, doesn't even touch the subject of art. What we teach is technique.

[ John Rea, p. 120]

In evaluating normal academic training, I find that there's too much of a division between history and theory. I've always felt that, if anything, I would like to have studied more of the philosophy and history of general ideas that accompany music history. I don't think that history and theory are placed in context in most music schools; it's too specialized. I don't know that there's a lot of non-Western music being taught in Canadian universities. Since I graduated, I've studied different kinds of music from non-Western perspectives. I would have liked to have that in university.

[ Paul Théberge ]

Judging from these comments and many others, one cannot escape the impression that much of the training received by composers (and, one suspects, by other musicians as well) in Quebec is rather narrow and pedantic. While no one disputes that a composer should have a broad general culture and solid professional training in his craft, in practice these goals are not generally being achieved. The composer who wants to be genuinely "educated," it seems, has a lot to do outside of school. It is my impression that, unlike their counterparts in Europe, or the U.S., many Quebec composers still look (and still need to look) outside their own country for a significant portion of their training.

\section{COMPOSITION}

The composers' discussions of their own work-processes constitute some of the most interesting parts of the interviews. Although I will mostly limit myself to shorter quotations about specific questions, two longer extracts, taken from the interviews with José Evangelista and Michel 
Longtin, articulate some more complex aspects of the compositional process.

Most of the composers see their work as a form of exploration, communication, and self-expression. They value the freedom of composition, where they can create a world as they please.

Creation is the place where I find pleasure in manipulating the material, where the rules are breakable; it is the translation of a reality that I try to organize and perhaps transform; it's the place where I try to understand a little about society and my place in it.

[ Michelle Boudreau, p. 24]

This sense of the liberty of art and of its special relation to life emerges again when the composers try to identify the sources of their inspiration: very few said that their ideas begin in purely musical form, as tones, rhythms, or timbres. Most attempt some kind of imitation of life, drawing on sources as diverse as poetry, science, the Cabala, the personal characteristics of the performers, etc. Composition is for them a way to understand the world and to come to grips with experience.

For me, composing is making sound objects/processes which I like. Composing is a learning experience which should reflect one's living experience. I wrote a piece for three pianos in sixth tones which uses Indian ragas, so from that experience I learned about Indian ragas . . ; I enjoy doing research that touches on historical or philosophical ideas. I find these kinds of projects more interesting and stimulating than an assignment to write an abstract piece that is only providing some entertainment for the ears.

[ John Winiarz, p. 147 ]

The first idea always comes from a feeling, an emotion related to a theme or a direction that grows out of preoccupations in my personal life or around me. This idea is tied to sound images, which I try to integrate with the theme, so as to communicate something, a "message."

[ Alain Lalonde, p. 86 ]

Once the initial inspiration has taken shape, the composers proceed in one of two ways. Fifteen of our interviewees usually begin with large-scale planning and then progress to detail. The planning may be as simple as a little graphic design of the shape of the work, or may involve serial structuring or complex calculation sometimes done with a computer. What all these composers have in common is that they cannot conceive the local details of their work without a prior sense of the whole. 
In the serious kind of piece it's partly the structural aspect that's important; sometimes I just start writing down ideas, but I have to have a plan of the piece to start with before I actually start writing different sections of it, so that I know what the proportional relationships between the sections are. So, it's mostly a question of techniques - of imagining certain kinds of music and of being able to plan out the time and evolution of the piece

[ Brian Cherney, p. 44 ]

Other composers begin with sketches and gradually build up the whole. They need the concrete reality of bits of music which then stimulate their sense of context and architecture.

When I start a piece I usually begin with concrete musical ideas . . . I then take these bits as starting points for continuations. I usually do a lot of rapid sketching at this point, trying to work out the lines of development. The large-scale form arises from the nature of the materials.

[ Robert Jones, p. 76]

While all the composers had clear preferences for one or the other of these two approaches, they are not, of course, mutually exclusive. The longer descriptions, below, by Evangelista and Longtin illustrate the interplay of structure and detail, stimulus and realization.

My pieces begin with the impression of a sound that might be the result of certain instruments or some more or less fluid combination. When I start to write, I begin with melodies, and I make lots of sketches.

I can at times have a pre-planned structure, but this would never be serial. I work like the composers of the Middle Ages, starting from a cantus firmus. This is because the cantus firmus is the source of my work. I have been doing this for three or four years.

I want to achieve a certain kind of sound or sonority, and I try to find the way; I experiment with many things. One thing I have done regularly for five or six years is to engage musicians. Before writing a piece, I write many sketches and I try them out. This tendancy to experiment with the musicians came to me from my meeting with Steve Reich. He works with musicians in this way. On the other hand, my music has nothing to do with Reich's, even though I use a similar method of work.

I also work at the piano. This is very important for me, except when I am working out a plan that gives a texture of which I am already sure. I don't hear everything internally. I don't think that many composers hear absolutely everything they write. I dislike the kind of person who pretends to hear everything sitting at a table. I don't 
believe in it, and I have a pretty good ear. One of the great musicians of our century, Stravinsky, always worked at the piano. Why?

When I get to the final version of a work, it is done very quickly. I spend a lot of time conceiving the work; the realization is done fast. Then, I make corrections when the work is played. I have even changed whole sections. My recent works are made of rather uniform textures. So if one part doesn't work, the whole section won't work, because of the uniform character.

There is a continuity from work to work, and recently I have noticed that one piece leads to another. For four or five years, I have developed things that are implicit in previous works.

[ José Evangelista, p. 51-52 ]

My first objective when I compose is to communicate. There is also an element of research, but oriented towards communication. My musical ideas come mainly from my passions, whether for a novel by Virgil Gheorghiu, a kata of incredible beauty in karate, music by Sibelius, or a painting from the Group of Seven. They are drives, which provoke in me a vision that I write down in my notebook. An example might be what I hear in looking at the painting "North River" by Tom Thompson. These things set off sounds in me, and I make sketches of them, which become more and more precise and transform themselves into musical lines. This way of starting composition with a sketch comes to me from electroacoustic composition; I think if I hadn't composed electroacoustic music, I couldn't write instrumental music. I hear sounds, and I sketch so as to remember them, since it's so easy to lose a musical idea. Then, I try to musically translate these ideas, and I choose an order, a macro-structure. I use the computer for rhythmic detail. This work on the structural level is not a constraint, but rather an open door, which makes it possible for me to hear things. The computer does not tell me what notes to write, but rather lays out a level of rhythm and harmony within which I choose, as Stibilj did in times past. So, in a sense it's completely aleatory. I do play the chord on the piano to make sure it really corresponds to my musical intentions. The opposite procedure seems to me dangerous.

Once the piece is done, I rarely revise, even after the première. My pieces are a way of life. I think that revising a piece after five years, because I keep rehearing it, is really thinking about posterity, trying to make it perfect, so that it will be played after my death. But I don't care if it's played after my death; what gives me pleasure is hearing it when I'm alive. I notice my mistakes and continue my own evolution.

[ Michel Longtin, p. 101] 
Once a work is completed (unless it is for tape alone) the performer joins the composer in the process of communication. Virtually all the composers seem very aware of their special and sometimes difficult relationship with performers: while they need performers, and depend on them to communicate the music effectively, they are also at the mercy of performers. They must challenge the performer and please him/her at the same time.

Rehearsals, for me, are painful moments, even harder than conceiving the work. They are moments of unbelievable dizziness. When the time comes for rehearsal, what happens is that the performers don't understand and it's audible. I have to explain everything and gradually things become clear ... (However) I am not the type of composer for whom it isn't worth the trouble ... I like to work with an instrumentalist and to see him transcend his instrument, as Liszt or Paganini did. It's important to work with musicians so they can evaluate their own instruments.

[ Michel-Georges Brégent, p. 40]

Although many of the composers regularly make minor adjustments to new works in rehearsal, only a small minority revises substantially once the work is finished. For one or two composers, however, this is an obsession: they want perfection and nothing less. However, many of those who do not revise find strong continuity from one work to the next: they feel that their artistic development is best served by moving on to the next project.

\section{AESTHETIC CONSIDERATIONS}

Perhaps because individuality is highly valued by most composers, only three - José Evangelista, Michel Longtin, and John Rea (interestingly, three of the oldest) spoke of their work as part of a larger current. In fact, however, many share aesthetic positions. Like young composers anywhere, those in Quebec are ambivalent about the past. On the one hand, they must assert themselves as new and different; on the other, much of their thinking is obviously influenced by their musical elders.

We wanted, specifically, to find out the composers' reaction to the current neo-romantic trend. A few composers are resolutely opposed to neo-romanticism in any form: they find it sterile, retrogressive, and uninteresting. A few welcome it wholeheartedly as a return to real "musical" values. Many others, reacting to the harshness of much music from the fifties and sixties, are trying, often with some unease, to find a 
way to integrate a more consonant sound and a wider expressive range into their musical vocabularies.

I am and we are all made from the past. I have a lot of respect for what has been done, but I am aware of it, and try to be philosophical about it. I retain from the past those works which have fascinated me - be it Mozart or Berlioz, Leonardo da Vinci or a contemporary painter; it's my "place of beauty." I try to enter into it, not to be equal to these people, but to be near to them. The past, for me, is always a way of seeing what is timeless in these beautiful things that I know. One cannot disassociate oneself from one's auditory historical memory. One thing is sure, however: when I do use a familiar musical gesture it no longer has the same meaning.

[ Denis Gougeon, p. 72 ]

This recovery of some aspects of tonal music was for me a way of achieving marvellous contrasts in a contemporary language ... (However) I don't think we have yet achieved the control to make a whole out of this marriage of tonal and atonal. I think we are still at the level of research.

[ Michel Longtin, p. 102]

... a judgement I made about ten years ago was that music had really changed and that it ought to examine certain areas in one's sensibility, as well as the listener's sensibility. Music ought to examine things that have been left unexamined: how listeners respond, what they do respond to, what really is the nature of the musical object that people listen to. Now, on the surface, and in many people's music, this re-examination was manifested in a music which was more consonant, more related to traditional rhythmic forms, was perhaps less aggressive than the previous generation's music . . . However, I don't think you should mistake the surface for the structure, as often happens in music. This wasn't the object of my particular interest - that music should get sweeter or more accessible. It was a means of examining other things inside of music that had been left actually undiscovered or unexamined.

[ John Rea, p. 122-3]

\section{CAREER}

This part of the interview examined the more mundane aspects of composing in Quebec today: earning a living, and the composer's relation to musical institutions. Like many composers elsewhere, most of our composers seem uneasy about the current state of affairs, where art music seems unimportant to society at large, and where composers therefore find themselves more often playing to their colleagues than to the public they want to reach. 
Although we did not ask directly how much money the interviewees earned from composing, it is clear that it is possible in only the rarest cases to make a living entirely from serious composition. The majority of our composers supplement their income with teaching, performing, and so on. In general, serious composition does not pay.

Only a minority (seven composers) has written functional music (music for films, TV, commercials etc.) A few other composers expressed interest in writing film music, even though they had not as yet had the opportunity to try. While realising its limitations, they are stimulated by the technical challenge of the medium.

Slightly less than half the composers write mainly on commission. The others write when they please, and find performances as they can. Only a few composers adapt their style consciously to commissions; all the others say they would be uninterested in a commission that didn't leave them totally free. Since the financial rewards of writing "serious" music are not great, most composers at least want to enjoy their freedom to do as they please.

Many of the composers were dissatisfied with the local musical institutions. The Montreal Symphony Orchestra was almost always singled out as the worst major institution in Quebec in its record on contemporary music. Several composers spoke of it as a "lost cause." On the other hand, many spoke positively about the role Radio Canada plays in their lives, while complaining that budget cuts have recently begun to eat away at what the radio can do. ${ }^{4}$

Most composers appreciate the role the contemporary music societies have played. Several, however, expressed discontent with the way repertoire was selected. They feel that "social" criteria often take precedence over musical ones.

We live in a situation where it is not the talent and competence of the composer that count, but rather to which clique he belongs. Since I am

4 Since the research for this article was conducted in 1984, there have been some changes. The MSO has recently appointed Denis Gougeon as composer-in-residence, a move that perhaps will lead to greater interest in contemporary music. Montreal now has a second major orchestra, the Orchestre Métropolitain, which has become active in promoting composers. The situation at Radio Canada, on the other hand, is getting worse, with less and less money available for new music programming and commissions. 
a loner, I don't have any expectations in this regard. We live in the prehistory of what will be a really honest diffusion of music, since today there are many sectarian and dishonest attitudes at the level where the choices are made.

[ Antoine Padilla, ]

\section{CULTURE}

The last area covered by our questionnaire was extra-musical: the importance of other disciplines to the composer and her/his attitudes to nationalism in music.

Virtually all of our interviewees have affinities with the visual arts and/or literature, often including regular personal contacts with other artists. A few composers, for example Walter Boudreau, mentioned strong interests in science; they said these contacts informed their work. I believe the structuralism of Garant and his school is an important influence here; many of his students start from mathematical and scientific notions when composing.

The last question we asked the composers concerned "cultural identity." We were curious, especially with respect to the francophone composers, to know to what extent they felt a need to identify their music as specifically Québecois. Was it important to them to manifest a distinct national character in their music, either through incorporating folklore or in subtler ways? While several composers pointed to obvious ways, such as using texts by Quebecois authors, in which their cultural heritage emerges in their work, almost all were more interested in achieving a "universal" appeal than in writing a strongly identifiable Québec music.

The solitary exception to this point of view is worth quoting.

I think it is fundamental that the artist manifest his cultural identity. There are many people who are for a sort of uniformization of all peoples. On the contrary, I believe very much in Canadian or Quebec music that is different from German or French music. I think that having the sort of universal contemporary musical language that finally meant nothing did a lot of harm in the fifties and the sixties. Music represents a culture, a society; it's absured to think that it can be the same in composers of different nationalities.

[ José Evangelista ] 


\section{CONCLUSION}

It will be noted that many of our findings could apply to any group of young contemporary composers. This was one of the surprising things that emerged from our work: apart from the obvious topical references to local institutions and personalities, there is not much difference between these Quebec composers and their colleagues elsewhere in the Western world. Quebec composers are distinctive as individuals, of course, but their general artistic preoccupations are more or less the same as those of young American or European composers of today. Perhaps this is inevitable in an era where communication and travel over long distances are so easy. Like most composers today, these people constitute a particularly mobile group. They frequently go to study, to work or to attend conferences elsewhere.

There seems to be something of a contradiction between the composers' insistence that they are not part of a larger group or trend and their view of themselves as "world" composers. There are certainly many common elements in their answers to our questions. In some cases, the resemblances are so strong that one could almost speak of a school. However, many aspects of this school are not limited to composers in Quebec.

To mention a few of the elements that were common to many composers: most of the French-Canadian composers (like many French composers) are still confronting serialism in some way; Garant's structuralism is still relevant to them. For the majority of their anglophone colleagues, on the other hand, the issue is dead; they are more influenced by current trends in the U.S. and elsewhere, such as minimalism and neo-romanticism. Many of the composers want to enlarge the sound world of music from the fifties and sixties, making a place for gentler, less aggressive sonorities. They are also more aware of performers than were many of the previous generation of composers. An international attitude is common: the sense that it is more important to belong to the world community than to emphasize one's separateness.

Overall, I was most struck by how much these composers share. As a composer myself, I felt part of a community. Despite great differences in temperament, style, training, and technique, all the composers are serious and dedicated, and all are trying to communicate what is important to them while exploring new ground. Their energy, commitment, and passion make Quebec an exciting place for new music. 


\section{APPENDIX 1: THE QUESTIONNAIRE}

\section{Musical Background}

a. events leading up to your choice of a career in music?

b. background as a performer?

c. training in writing skills; do you think it's necessary?

d. with which teacher(s) did you discover your creative talent?

e. overall evaluation of your own training?

\section{The Compositional Process}

a. your conception of composition: research or communication?

b. sources of inspiration, starting point for your work?

c. the stages of composition?

d. is there continuity between your works?

e. are you preoccupied by problems of interpretation in your works? Do you agree with Garant that JToo often the composers lose contact with the reality of instrumentalists"?

\section{Aesthetics}

a. what medium do you prefer: instrumental, electroacoustic, multi-media, functional music?

b. reaction to the current neo-romanticism?

c. is your aesthetic part of a present or past current trend, or is it a break with tradition?

d. your involvement in and opinion of the local musical community?

\section{Profession}

a. Do you write commercial music for money?

b. Do you only write on commission? If so, do you feel free to develop your own language, or are you trying in part to be 
accessible, to respond to the expectations of the commissioning group or its public?

c. Do the media and the local musical institutions (MSO, SMCQ, etc.) respond well to your needs?

\section{Culture}
a. affinities with other arts, other disciplines?
b. contact with people in other fields?
c. in 1984 , do you think it necessary to manifest your cultural identity in your music? If yes, why and how?

